dr hab. Ewa ROSZKOWSKA, prof. UwB

Wydział Ekonomii i Zarządzania, Uniwersytet w Białymstoku

e-mail: e.roszkowska@uwb.edu.pl

mgr Regina LAŠAKEVIČ

Wydział Ekonomiczno-Informatyczny w Wilnie, Uniwersytet w Białymstoku

e-mail: r.klukowska@uwb.edu.pl

DOI: $10.15290 /$ ose.2017.06.90.05

\title{
TAKSONOMICZNA ANALIZA ZRÓŻNICOWANIA ROZWOJU RYNKU PRACY NA LITWIE W LATACH 2004-2014
}

\begin{abstract}
Streszczenie
W opracowaniu podjęto próbę oceny zróżnicowania rozwoju rynku pracy w poszczególnych okręgach Litwy w latach 2004-2014. Prezentowane w artykule badanie składa się z dwóch etapów. Na pierwszym z nich dokonano analizy sytuacji na rynku pracy okręgów Litwy w latach 2004-2014. Stosując syntetyczny wskaźnik rynku pracy, wyznaczono rankingi okręgów Litwy oraz dokonano porównania zróżnicowania rozwoju rynku pracy w okręgach Litwy w badanym okresie. Na drugim etapie za pomocą metody porządkowania nieliniowego Warda wyodrębniono jednorodne grupy okręgów ze względu na podobną sytuację na rynku pracy. W latach 2004-2014 zaobserwowano wzrost międzyregionalnego zróżnicowania rozwoju rynku pracy okręgów Litwy. Najlepszą sytuację na rynku pracy w tym okresie odnotowano w okręgach: wileńskim, kowieńskim i kłajpedzkim. Wykorzystano dane Departamentu Statystyki Litwy.
\end{abstract}

Słowa kluczowe: rynek pracy, okręg, wielowymiarowa analiza porównawcza, metoda porządkowania liniowego, metoda Warda

\section{TAXONOMIC ANALYSIS OF DEVELOPMENT DISPARITIES OF LITHUANIAN LABOUR MARKET IN 2004-2014}

\section{Summary}

The paper attempts to assess the disparities in the development of the labour market in particular districts of Lithuania between 2004 and 2014. The study presented in the paper consists of two stages. The first one analyzes the situation of the labour market in the districts of Lithuania between 2004 and 2014. Using the synthetic indicator of the labour market, the Lithuanian districts are ranked and the development of the labour market in these districts is compared over the period considered. In the second stage, Ward's non-linear sorting method is used to divide the districts into homogeneous according to the situation in the labour market. In the years 2004-2004, there was an increase in interregional differences in the development of the labour market in the districts of Lithuania. The best situation during 
the period under review was noted in Vilniaus, Kauno, and Klaipedos districts. The author uses data of the Lithuanian Department of Statistics.

Key words: labour market, district, multi-dimensional comparative analysis, linear ordering method, Ward's method

JEL Classification: E24, E29, C19

\section{Wstęp}

Rynek pracy jest ważnym obszarem badawczym rozwoju społeczno-gospodarczego [Frączek, 2015; Kasperkiewicz, Madaj, 2012; Kryńska, Kwiatkowski, 2010]. Zasoby pracy, obok zasobów kapitału i zasobów naturalnych, stanowią tradycyjne czynniki rozwoju regionalnego. W literaturze przedmiotu rynek pracy jest analizowany w kontekście relacji między podażą pracy a popytem na pracę z uwzględnieniem ekonomicznych warunków gospodarowania [Bosworth, Dawkins, Stromback, 1996]. Rozmiary i struktura popytu na pracę mają wpływ na strukturę oraz dynamikę rozwoju gospodarki. Istotną rolę odgrywają także przygotowane zasoby pracy, ich kwalifikacje, jak również umiejętności związane z możliwościami szybkiego dostosowania się do zmieniających się warunków na rynku pracy.

Głównym celem badania jest ocena zróżnicowania rozwoju rynku pracy w poszczególnych okręgach Litwy w latach 2004-2014. Ocena poziomu rozwoju rynku pracy okręgów Litwy objęła: analizę wskaźnikową w podziale na cztery obszary tematyczne, takie jak: zatrudnienie, struktura pracujacych, uyykształcenie ludności, bezrobocie, uwzględniające stronę pobytową i podażową rynku pracy, uzyskanie rankingu w zakresie sytuacji na rynku pracy z wykorzystaniem syntetycznego miernika rynku pracy oraz pogrupowanie okręgów podobnych ze względu na sytuację na rynku pracy z zastosowaniem metody Warda.

Warto nadmienić, że wybrane aspekty rynku pracy Litwy w ujęciu makro- i mikroekonomicznym, państwa i regionalnym były przedmiotem badań szeregu opracowań naukowych [Vaitekūnas, Stefanenkova, 2011; Vetlov, Virbickas, 2006]. Dotyczyły one m.in.: bezrobocia, struktury zatrudnienia, wynagrodzenia brutto w okręgach Litwy, oceny pozycji Litwy czy wybranych okręgów na tle innych krajów [VerkulevičiūtèKriukienė, 2015; Čiburienè, Guščinskienė, 2008; Vaitekūnas, 2008], integracji osób młodych z istniejącym systemem pracy [Adomaitytè, 2014; Braziené, Dorelaitiené, 2013; Laužadyte, Samoškaité, 2013]. Jednak brakuje kompleksowej oceny poziomu zróżnicowania Litwy w obszarze rynku pracy w ujęciu czasowo-przestrzennym. Dane opracowanie ma posłużyć wypełnieniu luki badawczej w badanym zakresie.

Rynek pracy w kontekście rozwoju społeczno-gospodarczego okręgów Litwy opisano za pomocą zmiennych diagnostycznych, powiązanych z tym pojęciem merytorycznie. Do analizy zróżnicowania rynku pracy użyto metody wielowymiarowej analizy porównawczej (WAP), które pomogły ocenić poziom zróżnicowania badanego zjawiska 
w ujęciu regionalnym oraz wyznaczyć trendy zmian w tym obszarze ${ }^{1}$ [Roszkowska, Filipowicz-Chomko, 2016; Roszkowska, Karwowska, 2014; Perło, Roszkowska, 2011; Malkowski, 2007]. Wykorzystując syntetyczny wskaźnik rynku pracy, wyznaczono rankingi okręgów Litwy oraz dokonano porównania zróżnicowania rozwoju rynku pracy w okręgach Litwy w latach 2004-2014. Za pomocą metody porządkowania nieliniowego Warda wyodrębniono jednorodne grupy okręgów ze względu na podobną sytuację na rynku pracy. Posłużono się danymi Departamentu Statystyki Litwy.

Opracowanie składa się z czterech części. W części drugiej przedstawiono metodologię badania, w tym omówiono konstrukcję syntetycznego miernika rynku pracy. W trzeciej części dokonano oceny zróżnicowania rozwoju rynku pracy okręgów Litwy w latach 2004-2014 za pomoca syntetycznego miernika rynku pracy oraz metody Warda. W podsumowaniu zawarto ogólne wnioski.

\section{Metodologia badania}

Metody wielowymiarowej analizy porównawczej (WAP) są wykorzystywane do oceny zróżnicowania przestrzennego zjawisk społeczno-ekonomicznych [Młodak, 2006, Malina, 2014]. W opracowaniu miernik syntetyczny, będący funkcją znormalizowanych wartości zmiennych wejściowych, użyto do utworzenia rankingu pod względem sytuacji na rynku pracy okręgów Litwy. Zmienna syntetyczna pozwoliła na uwzględnienie zarówno strony podażowej, jak i popytowej rynku pracy. Metodą porządkowania nieliniowego Warda posłużono się do wyodrębnienia skupisk regionów Litwy, które są najbardziej podobne do siebie wewnątrz grup oraz najbardziej zróżnicowane z uwagi na poziom rynku pracy. Zastosowanie wskaźników indywidualnych, metody porządkowania liniowego oraz porządkowania nieliniowego umożliwiło kompleksową analizę sytuacji rynku pracy w okręgach Litwy w ujęciu czasowo-przestrzennym² ${ }^{2}$.

Metodologia badania rozwoju rynku pracy w poszczególnych okręgach Litwy w latach 2004-2014 przebiegała według poniższej procedury.

1. Ustalono listę potencjalnych cech diagnostycznych oraz określono ich charakter, wskazując stymulanty i destymulanty.

Biorąc pod uwagę przesłanki merytoryczne, a także dostępność informacji statystycznej, na wstępie ustalono zestaw dwunastu potencjalnych zmiennych diagnostycznych (tabela 1.) kształtujących sytuację na rynku pracy danego regionu, pogrupowanych w podobszary tematyczne, takie jak: zatrudnienie, struktura pracujacych, mylksżtałcenie ludności, bearobocie. Zakres przestrzenny badań dotyczył

1 Niniejsze opracowanie jest kontynuacją badań dotyczących oceny poziomu rozwoju rynku pracy okręgów Litwy w latach 2004-2014. Pierwsze badanie zawierało analizę wskaźnikową zróżnicowania poziomu rynku pracy okręgów Litwy w latach 2004-2014, która objęła regionalne zróżnicowanie wartości zmiennych objaśniających rynek pracy w ujęciu przestrzennym oraz czasowym dzięki analizie dynamiki zmian wartości tych zmiennych w obrębie każdego podobszaru tematycznego.

2 Szerzej o metodach porządkowania liniowego i nieliniowego, w tym ich zaletach, ograniczeniach, np. w: [Młodak 2006, Malina, 2014]. 
poszczególnych okręgów Litwy. Zakres czasowy badań obejmował lata 20042014.

2. Zredukowano zbiór potencjalnych cech diagnostycznych, eliminując cechy odznaczające się relatywnie niską zmiennościa, wykorzystując wartości współczynnika zmienności (poniżej 10\%), a także zbyt silnie skorelowane $z$ innymi cechami diagnostycznymi, posługując się w tym celu analizą diagonalnych elementów macierzy odwrotnej współczynników korelacji [Młodak, 2006, s. 28-33].

3. Dokonano normalizacji zmiennych diagnostycznych zgodnie z formułą unitaryzacji zerowanej [Malina, 2014, s. 32-35]:

a) dla stymulant: $Z_{i k t}=\frac{R P_{i k t}-\min _{i}\left\{R P_{i k t}\right\}}{\max _{i}\left\{R P_{i k t}\right\}-\min _{i}\left\{R P_{i k t}\right\}}$;

b) dla destymulant: $Z_{i k t}=\frac{\max _{i}\left\{R P_{i k t}\right\}-R P_{i k t}}{\max _{i}\left\{R P_{i k t}\right\}-\min _{i}\left\{R P_{i k t}\right\}}$;

gdzie: $i$ - numer okręgu $(i=1,2, \ldots, n=10) ; k$ - numer wskaźnika rynku $\operatorname{pracy}(k=1,2, \ldots, m) ; t-\operatorname{rok}(t=2004,2005, \ldots, 2014)$;

- $\max _{i}\left\{R P_{i k t}\right\}$ - maksymalna wartość $k$-tego wskaźnika rynku pracy w latach 2004-2014;

- $\min _{i}\left\{R P_{i k t}\right\}$ - minimalna wartość k-tego wskaźnika rynku pracy w latach 2004-2014.

4. Wyznaczono wartości syntetycznego miernika rynku pracy dla $i$-tego okręgu oraz $t$-go roku, stosując metodę konstrukcji miernika, polegającą na uśrednieniu znormalizowanych wartości wskaźników indywidualnych:

$$
q_{i t}=\frac{1}{m} \sum_{k=1}^{m} z_{i k t}
$$

gdzie: $i$ - numer okręgu $(i=1,2, \ldots, 10) ; k$ - numer wskaźnika rynku pracy $(k=1,2, \ldots, m) ; t-\operatorname{rok}(t=2004,2005, \ldots, 2014)$;

- $\quad z_{i k t}-$ znormalizowana wartość $k$-tego wskaźnika rynku pracy

$(k=1,2, \ldots, m)$ dla $i$-tego okręgu $(i=1,2, \ldots, 10)$ w $t$-tym roku

$(t=2004,2005, \ldots, 2014)$;

- $\quad q_{i t}$ - wartość syntetycznej miary dla $i$-tego okręgu $(i=1,2, \ldots, 10)$

w $t$-tym roku $(t=2004,2005, \ldots, 2014)$.

Wartości syntetycznego miernika $q_{i t}$ należą do przedziału $<0,1>$. Wyższe wartości syntetycznego miernika świadczą o wyższej pozycji okręgu w danym rankingu.

5. Uporządkowano liniowo okręgi Litwy ze względu na wartość syntetycznego miernika oraz dokonano podziału okręgów na cztery klasy. 
Wykorzystując średnią arytmetyczną $\left(\overline{q_{t}}\right)$ i odchylenie standartowe $\left(s_{q t}\right)$ dla wartości syntetycznego miernika rynku pracy, dokonano podziału okręgów na cztery klasy dla $t$-go roku w latach 2004-2014, zgodnie ze wzorem:

- $\quad$ klasa I (poziom wysoki): $q_{i t} \geq \overline{q_{t}}+s_{q t}$;

- $\quad$ klasa II (poziom średni wyższy): $\overline{q_{t}}+s_{q t}>q_{i t} \geq \overline{q_{t}}$;

- $\quad$ klasa III (poziom średni niższy): $\overline{q_{t}}>q_{i t} \geq \overline{q_{t}}-s_{q t}$;

- $\quad$ klasa IV (poziom niski): $q_{i t}<\overline{q_{t}}-s_{q t}$.

Dany podział posłużył określeniu sytuacji na rynku pracy Litwy w ujęciu przestrzennym i czasowym.

Grupowanie okręgów do typologicznych klas rynku pracy poddano ocenie zdolności dyskryminacyjnych skonstruowanych mierników. W tym celu wyznaczono współczynnik $G_{i}$ Sokołowskiego [Sokołowski, 1984]:

$$
G_{t}=1-\sum_{i=1}^{n-1} \min \left\{\frac{q_{i t}-q_{i+1, t}}{R_{t}}, \frac{1}{n-1}\right\}
$$

gdzie:

- $\quad R_{t}=\max _{i}\left\{q_{i t}\right\}-\min _{i}\left\{q_{i t}\right\}$

- $\quad q_{i t}, q_{i+1, t}-$ uporządkowane nierosnąco wartości miernika.

Wskaźnik $G_{t}$ przyjmuje wartości z przedziału $\left[0 ; 1-\frac{1}{n-1}\right]$. Wysokie wartości wskaźnika wskazują na dużą zdolność miernika taksonomicznego do grupowania.

6. Dokonano grupowania okręgów za pomocą metody Warda.

Wyniki grupowania otrzymane za pomoca metody Warda z normalizacja zmiennych w zakresie 0-1 i metryką równą kwadratowi odległości euklidesowej [szerzej: Wójcik, 2009] przedstawiono graficznie w postaci dendrogramów 3 .

\section{Ocena zróżnicowania sytuacji na rynku pracy na Litwie w latach 2004-2014}

Początkowy zbiór indywidualnych wskaźników rynku pracy okręgów Litwy obejmował dwanaście wskaźników, pogrupowanych w podobszary tematyczne, takie jak: zatrudnienie, struktura pracujacych, wykesztatcenie ludności, bezrobocie. W tabeli 1. zaprezentowano ogólne charakterystyki opisowe wskaźników rynku pracy.

3 Dendrogram to diagram w kształcie drzewa ukazujący związki między badanymi obiektami na podstawie przyjętych kryteriów. W metodzie Warda dendrogram ilustruje kolejne etapy (iteracje) procesu grupowania - od liści (pojedynczych regionów) do korzenia (jednego skupienia). 
TABELA 1.

\section{Podstawowe charakterystyki opisowe zmiennych objaśniających obszar tematyczny rynku pracy dla okręgów Litwy w latach 2004 i 2014}

\begin{tabular}{|c|c|c|c|c|c|c|c|c|}
\hline \multirow[b]{2}{*}{ 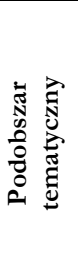 } & \multirow[b]{2}{*}{ 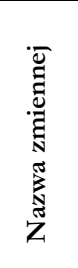 } & \multirow[b]{2}{*}{ 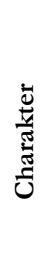 } & \multirow[b]{2}{*}{$\frac{y}{0}$} & \multicolumn{5}{|c|}{ Statystyki opisowe } \\
\hline & & & & 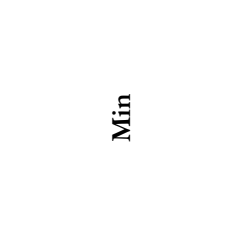 & $\sum_{i}^{\stackrel{x}{J}}$ & $\frac{\pi}{\stackrel{\Xi}{E}}$ & 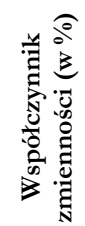 & 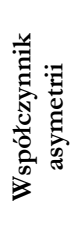 \\
\hline \multirow{6}{*}{ 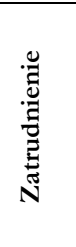 } & \multirow{2}{*}{ RP1 } & \multirow{2}{*}{$\mathrm{D}$} & 2004 & 58 (wileński) & 75 (tauroski) & 68,80 & 8,14 & $-0,92$ \\
\hline & & & 2014 & 57 (wileński) & 65 (poniewieski) & 63,13 & 4,02 & $-1,94$ \\
\hline & \multirow{2}{*}{ RP2 } & \multirow{2}{*}{ S } & 2004 & 65,30 (olicki) & 71,60 (wileński) & 68,07 & 2,84 & 0,55 \\
\hline & & & 2014 & 70,50 (poniewieski) & 76,80 (wileński) & 72,56 & 2,71 & 1,19 \\
\hline & \multirow{2}{*}{ RP3 } & \multirow{2}{*}{ S } & 2004 & 55,60 (olicki) & 63,90 (wileński) & 60,66 & 4,11 & $-0,72$ \\
\hline & & & 2014 & 58,30 (olicki) & 70,20 (wileński) & 63,39 & 6,15 & 0,71 \\
\hline \multirow{6}{*}{ 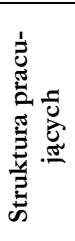 } & \multirow{2}{*}{ RP4 } & \multirow{2}{*}{$\mathrm{D}$} & 2004 & 51 (wileński) & 422 (tauroski) & 211,81 & 48,67 & 0,58 \\
\hline & & & 2014 & 28 (wileński) & 298 (tauroski) & 134,14 & 56,55 & 1,07 \\
\hline & \multirow{2}{*}{ RP5 } & \multirow{2}{*}{ S } & 2004 & 195 (tauroski) & 360 (telszański) & 279,95 & 18,85 & $-0,18$ \\
\hline & & & 2014 & 206 (tauroski) & 345 (telszański) & 261,55 & 17,28 & 0,66 \\
\hline & \multirow{2}{*}{ RP6 } & \multirow{2}{*}{ S } & 2004 & 383 (tauroski) & 677 (wileński) & 508,20 & 17,74 & 0,32 \\
\hline & & & 2014 & 496 (tauroski) & 765 (wileński) & 603,94 & 13,37 & 0,72 \\
\hline \multirow{8}{*}{ 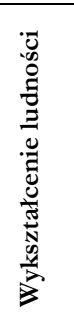 } & \multirow{2}{*}{ RP7 } & \multirow{2}{*}{ S } & 2004 & 0 (tauroski) & 17 (wileński) & 5,90 & 101,75 & 1,06 \\
\hline & & & 2014 & 0 (tauroski) & 20 (wileński) & 6,42 & 109,96 & 1,18 \\
\hline & \multirow{2}{*}{ RP8 } & \multirow{2}{*}{$\mathrm{D}$} & 2004 & 10,24 (wileński) & 19,91 (szawelski) & 14,86 & 23,07 & 0,32 \\
\hline & & & 2014 & 4,23 (wileński) & 14,61 (tauroski) & 8,27 & 37,07 & 0,82 \\
\hline & \multirow{2}{*}{ RP9 } & \multirow{2}{*}{ S } & 2004 & 14,14 (telszański) & 35,41 (wileński) & 21,87 & 27,85 & 1,07 \\
\hline & & & 2014 & 18,17 (tauroski) & 45,70 (wileński) & 30,96 & 27,65 & 0,34 \\
\hline & \multirow[t]{2}{*}{ RP10 } & \multirow{2}{*}{ S } & 2004 & 11,94 (telszański) & 30,50 (wileński) & 18,88 & 28,00 & 0,99 \\
\hline & & & 2014 & 15,22 (tauroski) & 40,36 (wileński) & 26,76 & 29,06 & 0,36 \\
\hline \multirow{4}{*}{ 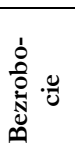 } & \multirow[t]{2}{*}{ RP11 } & \multirow{2}{*}{$\mathrm{D}$} & 2004 & 7,40 (mariampolski) & 38,70 (uciański) & 22,47 & 46,70 & 0,35 \\
\hline & & & 2014 & 12,30 (kłajpedzki) & 41,60 (olicki) & 24,06 & 38,56 & 0,36 \\
\hline & \multirow[t]{2}{*}{ RP12 } & & 2004 & 6,60 (mariampolski) & 14,60 (olicki) & 10,82 & 21,18 & $-0,35$ \\
\hline & & $\mathrm{D}$ & 2014 & 7,70 (kłajpedzki) & 18,50 (olicki) & 12,46 & 28,65 & 0,39 \\
\hline
\end{tabular}

Źródło: opracowanie własne na podstawie danych Departamentu Statystyki Litwy.

\section{Podobszar tematyczny: zatrudnienie}

Pierwszy wskaźnik podobszaru tematycznego zatrudnienie: obciążenie demograficzne (RP1) definiowany jako liczba ludności w wieku nieprodukcyjnym (przedprodukcyjnym i poprodukcyjnym) przypadająca na 100 osób w wieku produkcyjnym charakteryzuje, jak szybko starzeje się badane społeczeństwo. Niekorzystnym zjawiskiem dla rozwoju gospodarczego okręgów jest zwiększająca się wartość tego wskaźnika. Drugi wskaźnik: współczynnik aktywności zawodowej (RP2), zgodnie z definicją Departamentu Statystyki Litwy, określany jest procentowo jako relacja siły roboczej do ogólnej 
liczby ludności [Stownik. DSL]. W tym przypadku mowa o aktywności zawodowej osób w wieku 15-64 lata. Większa wartość współczynnika aktywności zawodowej oznacza, że więcej osób w wieku produkcyjnym pracuje zawodowo. Ostatni wskaźnik z tego podobszaru: wskaźnik zatrudnienia (RP3), zgodnie z definicją Departamentu Statystyki Litwy, wyznacza procentowy udział wybranej grupy wiekowej osób pracujących w ogólnej liczbie ludności dotyczącej wybranej grupy wiekowej, którą są mieszkańcy okręgów w wieku 15-64 lata. Wysoka wartość wskaźnika zatrudnienia jest: warunkiem koniecznym uayskkania spójności społeç̨no-gospodarczej [Perło, 2014, s. 129].

\section{Podobszar tematyczny: struktura pracujących}

Pracujący w poszczególnych trzech sektorach ekonomicznych, tj.: rolniczym (rolnictwo, leśnictwo, rybołówstwo), przemysłowym (przemysł i budownictwo), usługowym pozwalają zmonitorować kierunek gospodarczy badanego okręgu. Podstawą zaklasyfikowania pracujących do poszczególnych sektorów ekonomicznych jest obowiązująca Klasyfikacja Działalności na Litwie 2007 [Ustawa z dnia 31 października 2007 roku...]. Pierwszy wskaźnik z podobszaru tematycznego struktura pracujacych dotyczy: liczby osób pracujących w rolnictwie, leśnictwie i rybołówstwie na 1000 pracujących (RP4), drugi liczby pracujących w przemyśle i budownictwie na 1000 pracujących (RP5), a trzeci liczby pracujących w usługach na 1000 pracujących (RP6). Wysokie wartości wskaźnika RP6 świadczą o prawidłowym kierunku rozwoju gospodarczym okręgów.

\section{Podobszar tematyczny: wykształcenie ludności}

Rola edukacji jest bardzo ważna, gdyż służy zmniejszaniu się nierówności społecznych, a także daje podstawy do poprawy pozycji na rynku pracy w przyszłości. Pierwszym analizowanym wskaźnikiem z podobszaru tematycznego myksstatcenie ludności jest liczba absolwentów mających wyższe wykształcenie na 1000 ludności (RP7). Wykształcenie wyższe na Litwie można uzyskać po ukończeniu uniwersytetu (cztery lata studiów) albo kolegium (trzy lata studiów). Kolegia są to instytucje oświatowe, które rozpoczęły swą działalność w 2000-2001 roku akademickim. Absolwenci danych kolegiów otrzymują wykształcenie wyższe zawodowe. Zasadniczym celem powstania kolegiów było zwiększenie dostępności do szkolnictwa wyższego oraz zmniejszenie zróżnicowania w wykształceniu ludności w okręgach [Łuczyńska, 2015, s. 202-203].

Bardzo istotnym wskaźnikiem z podobszaru tematycznego wyksżtałcenie ludności jest udział osób $\mathrm{z}$ wykształceniem podstawowym lub niepełnym podstawowym wśród mieszkańców w wieku 25-64 lata (RP8). Dany wskaźnik jest oparty na metodologii Międzynarodowej Standardowej Klasyfikacji Kształcenia (ISCED). Do osób z podstawowym lub niepełnym podstawowym wykształceniem (ISCED 0,1,2) są zaliczane osoby posiadające wykształcenie: przedszkolne, początkowe i podstawowe. Kolejnym analizowanym wskaźnikiem z podobszaru tematycznego ayłkształcenie ludności jest udział 
osób z wyższym ${ }^{4}$ wykształceniem wśród mieszkańców 25-64 lata (RP9). Wskaźnik ten, podobnie jak i poprzedni, jest obliczany jako wskaźnik ISCED, w którym są brane pod uwage poziomy 5. i 6 . Ostatnim wskaźnikiem z podobszaru tematycznego ayłkształcenie ludności jest udział osób z wykształceniem wyższym w ludności w wieku produkcyjnym (RP10).

\section{Podobszar tematyczny: bezrobocie}

Pierwszym wskaźnikiem z obszaru tematycznego bęrobocie jest stopa bezrobocia rejestrowanego wśród osób 15-24 lata (RP11), czyli wśród młodych. Kolejnym wskaźnikiem jest stopa bezrobocia rejestrowanego wśród osób od 15 lat i powyżej (RP12). Według Departamentu Statystyki Litwy, dany wskaźnik jest liczony jako udział liczby zarejestrowanych bezrobotnych w zasobach siły roboczej.

Uwzględniając przesłanki merytoryczno-statystyczne, początkowy zestaw wskaźników rynku pracy zredukowano do siedmiu wskaźników, takich jak: RP3, RP5, RP6, RP7, RP8, RP11, RP125.

Wartości obliczonych wskaźników syntetycznych poziomu rynku pracy w poszczególnych okręgach Litwy w latach 2004-2014 zawiera tabela 2. Wykorzystując średnią arytmetyczną i odchylenie standardowe z wartości mierników syntetycznych, dokonano podziału okręgów na cztery klasy, tj.: o dobrej, średnio dobrej, średnio słabej lub słabej sytuacji na rynku pracy. Za pomocą różnych odcieni szarości uwzględniono przynależność okręgów do klas typologicznych (tabela 2.).Wartości wskaźnika G świadcza o tym, że mierniki syntetyczne rynku pracy charakteryzują się umiarkowaną zdolnością do podziału okręgów Litwy na grupy typologiczne pod względem rozwoju rynku pracy (tabela 2.). Przy czym, najwyższą zdolność dyskryminacyjną $(0,484)$ zaobserwowano dla 2012 roku, najniższą $(0,196)$ dla 2014 roku.

Zróżnicowanie okręgów Litwy w zakresie sytuacji na rynku pracy należy uznać za umiarkowane. Współczynnik zmienności ustalony na podstawie względnych mierników poziomu rynku pracy zawierał się w granicach: od 15,473\% w 2008 roku do 30,816\% w 2010 roku. Rozkład ustalonych mierników dla większości lat cechował się silną lub bardzo silną asymetrią prawostronna, co jest dowodem na to, że w większości okręgów syntetyczny miernik rynku pracy miał wartości niższe od średniej. Jedynie w 2008 roku współczynnik asymetrii dla syntetycznego miernika rynku pracy przyją wartość ujemną.

Analiza wartości miernika rynku pracy w latach 2004-2014 pokazuje dość duże zróżnicowanie tempa i kierunku zmian rozwoju rynku pracy okręgów Litwy (rysunek 1.). W 2007 roku syntetyczny miernik osiągał największe wartości w badanym okresie (przedział: [0,445; 0,782]), w 2010 roku najmniejsze wartości (przedział: [0,255; 0,612]).

\footnotetext{
4 Pod uwagę jest brane wykształcenie wyższe uniwersyteckie (po ukończeniu uniwersytetu) i wyższe nieuniwersyteckie (po ukończeniu kolegium).

5 Ważnym kryterium wyboru zmiennych diagnostycznych było reprezentowanie wszystkich podobszarów tematycznych dotyczących rynku pracy. Stąd, ze względu niską zmienność (poniżej 10\%) wszystkich zmiennych, do dalszej analizy została wzięta zmienna RP3, odznaczająca się najwyższą zmiennością spośród pozostałych.
} 


\begin{tabular}{|c|c|c|c|c|c|c|c|c|c|c|c|c|c|c|c|c|c|}
\hline p.̊urey & $\sigma$ & i & & & & & & & & $\dot{-i}$ & & & & & & & \\
\hline troz & 的 & है. & 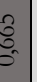 & the & 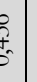 & 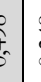 & & & & & & & & $\frac{F}{\partial}$ & : & & $\frac{0}{0}$ \\
\hline Rợuxy & $\therefore$ & $\mathrm{N}$ & i. & 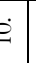 & $\infty^{\circ}$ & & 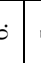 & & si & $\rightarrow$ & & & & & & & \\
\hline घ10乙 & ఫે & & 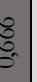 & : & . & 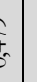 & 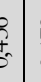 & 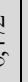 & $\bar{b}$ & $0^{\circ}$ & & & 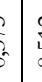 & $\frac{\alpha}{c}$ & 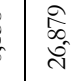 & & 桌 \\
\hline R.̊ư & + & त & $\therefore$ & $\therefore$ & -1 & & $\circ$ & & $\dot{\theta}$ & $\therefore$ & & & & & & & \\
\hline zाoz & 变 & 苞 & to & . & . & 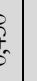 & 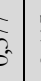 & 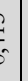 & 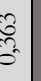 & 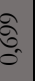 & & & 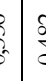 & $\frac{\bar{c}}{a}$ & 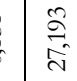 & & 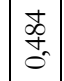 \\
\hline Ro̊̆uxy & $\dot{0}$ & i & 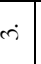 & 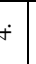 & $=1$ & & 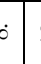 & & & $\therefore$ & & & & & & & \\
\hline L10Z & $\begin{array}{l}\infty \\
\infty^{2} \\
\delta^{2}\end{array}$ & 品. & $\begin{array}{c}0 \\
0 \\
0 \\
0 \\
0\end{array}$ & 等. & . & & & & $\hat{\theta}$ & ". & & & 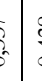 & 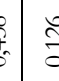 & : & $\left|\begin{array}{l}0 \\
\dot{s} \\
0 \\
0\end{array}\right|$ & F \\
\hline ฉợuxy & $\dot{+}$ & ה & •. & $\cdot$ & 6 & & $\dot{\vec{z}}$ & & i. & $\therefore$ & & & & & & & \\
\hline $000 z$ & $\begin{array}{l}\text { ond } \\
c^{2}\end{array}$ & $\begin{array}{l}\sqrt{n} \\
0 \\
0.1\end{array}$ & $\begin{array}{l}\text { of } \\
\text { of } \\
\end{array}$ & : & f. & $\begin{array}{l}0 \\
0 \\
0 \\
3^{2}\end{array}$ & 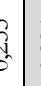 & & 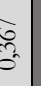 & ") & & & 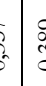 & $\check{c}$ & $\mid \begin{array}{l}\infty \\
0 \\
0 \\
0 \\
0\end{array}$ & $\begin{array}{l}\tilde{B} \\
0 \\
0\end{array}$ & 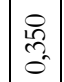 \\
\hline e.̊uey & in & $\mathrm{A}$ & ๓ं & . & & & 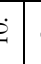 & & + & $\therefore$ & & & & & & & \\
\hline $600 z$ & $\begin{array}{l}\text { fo } \\
0 \\
0\end{array}$ & t. & 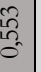 & $\begin{array}{l}\text { fon } \\
\text { of }\end{array}$ & 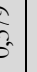 & for & of & & 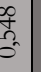 & 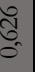 & & & & 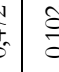 & 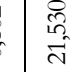 & $\begin{array}{l}\text { 心్ల. } \\
\tilde{\sigma}^{2}\end{array}$ & 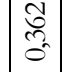 \\
\hline R.̊üey & $\dot{+}$ & त & 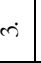 & $\infty$ & : & & & & . & $\therefore$ & & & & & & & \\
\hline $800 z$ & 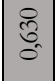 & 弪 & 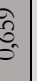 & b & 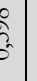 & 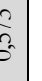 & & & : & 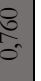 & & & & 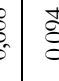 & 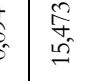 & 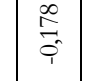 & त्रे \\
\hline Ro̊uey & + & i & $\therefore$ & . & $\therefore$ & & & & $\infty^{\circ}$ & $\therefore$ & & & & & & & \\
\hline$\angle 00 z$ & 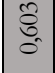 & 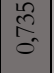 & 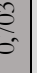 & b & 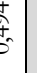 & 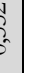 & & & ty & 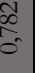 & & & 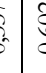 & & 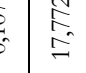 & $\begin{array}{l}0 \\
0 \\
0 \\
0\end{array}$ & 总 \\
\hline Ro̊uey & + & त & $\therefore$ & 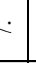 & & & & & r. & $\therefore$ & & & & & & & \\
\hline $900 z$ & ह్ర & $\mid$ & d. & ?3 & 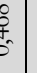 & & $\begin{array}{l}f \\
f \\
b\end{array}$ & & 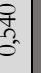 & & & & & & {$\left[\begin{array}{c}\infty \\
0 \\
0 \\
0\end{array}\right.$} & & of \\
\hline posuey & 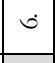 & i & $\therefore$ & $\cdot$ & & & 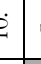 & & + & $\therefore$ & & & & & & & \\
\hline$\varsigma_{000}$ & 等等 & | & है & 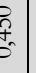 & s. & $\frac{f}{8}$ & 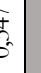 & 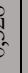 & 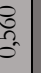 & $\theta^{\prime \prime}$ & & & & & 营 & & 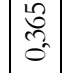 \\
\hline p.̊uvey & $\therefore$ & i & $\therefore$ & + & & 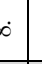 & $=$ & & 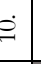 & $\therefore$ & & & & & & & \\
\hline t00z & $\mid \begin{array}{l}0 \\
\vdots \\
0 \\
0 \\
0\end{array}$ & & 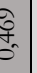 & 等 & 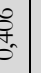 & 3 & & & 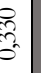 & & & & & & 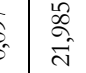 & & $\begin{array}{l}\pi \\
\tilde{\sigma} \\
0\end{array}$ \\
\hline 峞 & & & & & & & & & & & & & & & & & \\
\hline
\end{tabular}


Zróżnicowanie pozycji okręgów w rankingach ze względu na miernik rynku pracy w badanym okresie było duże. Jedynie trzy okręgi miały stabilne i wiodące pozycje, tj.: wileński (pozycja 1.), kowieński (pozycja 2.) i kłajpedzki (pozycja 3.). Dla pozostałych okręgów odnotowano duże zmiany pozycji. Analiza wartości syntetycznego miernika pozwala na wyodrębnienie trzech okresów rozwoju rynku pracy dla Litwy: umiarkowany rozwój rynku pracy (lata 2004-2007); niski rozwój rozwoju rynku pracy (lata 2008-2010) oraz umiarkowany rozwój rynku pracy (lata 2011-2014). Wyjaśnieniem takiego tempa i kierunku rozwoju rynku pracy jest początek gospodarczego kryzysu światowego w 2008 roku. Jednak, porównując wartości miernika z 2014 roku z 2004 rokiem, zauważa się poprawę sytuacji na rynku pracy w okręgach Litwy w badanym okresie. Wysoki rozwój rynku pracy w latach 2004-2014 reprezentował jedynie okręg wileński. Natomiast okręgi kowieński i kłajpedzki na początku badanego okresu wykazywały średnio dobrą sytuację na rynku pracy, a następnie dobrą sytuację na rynku pracy. W przypadku pozostałych okręgów stwierdzono duże zróżnicowanie okręgów ze względu na przynależność do klasy typologicznej. Największe zróżnicowanie w przynależności do klas typologicznych zaobserwowano dla okręgu uciańskiego, który w latach 2004-2014 charakteryzował się słabą, średnio dobrą i średnio słabą sytuacją na rynku pracy. Na uwagę zasługuje także okręg mariampolski, który w latach 2004-2014 reprezentował średnio słabą sytuację na rynku pracy. Odnotowano spadek pozycji okręgu mariampolskiego w rankingach w 2014 roku w porównaniu z 2004 rokiem, tj. z 4. pozycji na 8. pozycję.

\section{Wartości syntetycznego miernika rynku pracy dla okręgów Litwy w latach 2004-2014}

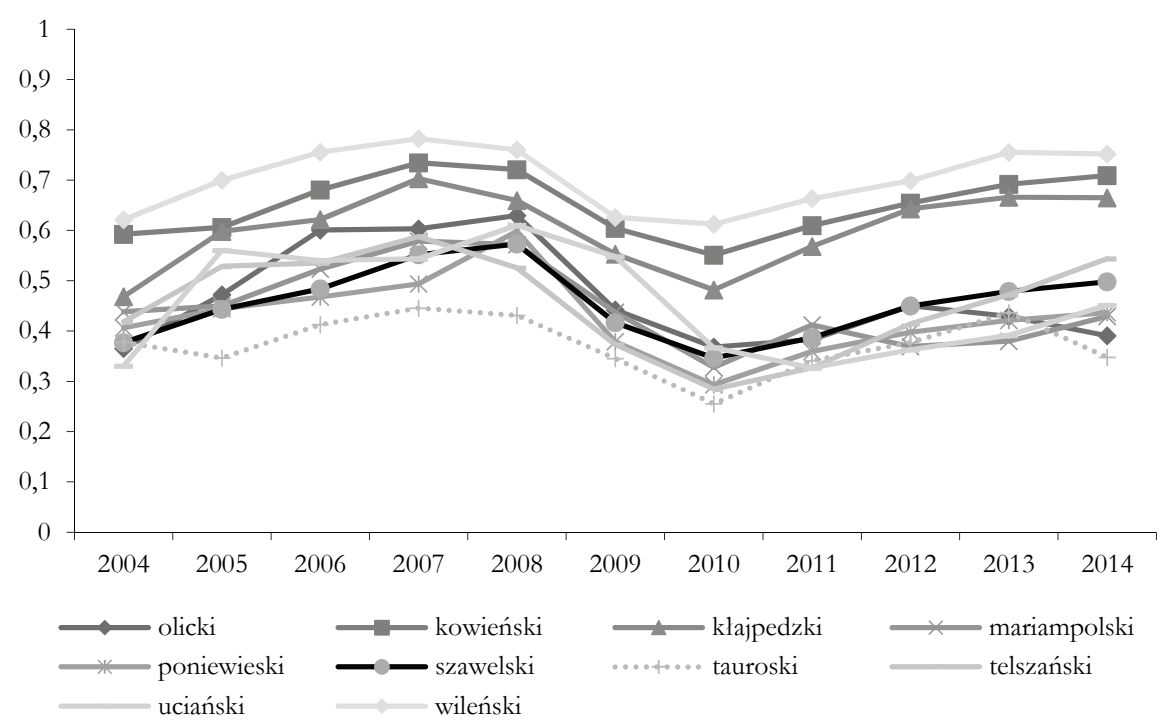

Źródło: opracowanie własne na podstawie danych Departamentu Statystyki Litwy. 
TABELA 3.

Zmiany wartości syntetycznego miernika rynku pracy dla okręgów Litwy w latach 2004-2014

\begin{tabular}{|c|c|c|c|c|c|c|c|c|c|c|}
\hline Okręg & 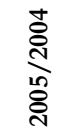 & 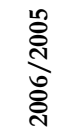 & 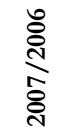 & 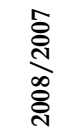 & 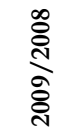 & 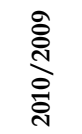 & 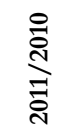 & 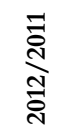 & 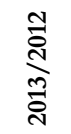 & 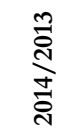 \\
\hline olicki & 0,107 & 0,129 & 0,002 & 0,026 & $-0,188$ & $-0,074$ & 0,015 & 0,067 & $-0,021$ & $-0,038$ \\
\hline kowieński & 0,014 & 0,075 & 0,054 & $-0,014$ & $-0,117$ & $-0,053$ & 0,059 & 0,045 & 0,037 & 0,018 \\
\hline kłajpedzki & 0,130 & 0,023 & 0,081 & $-0,044$ & $-0,106$ & $-0,071$ & 0,086 & 0,075 & 0,023 & $-0,001$ \\
\hline mariampolski & 0,012 & 0,074 & 0,055 & $-0,007$ & $-0,134$ & $-0,110$ & 0,084 & $-0,043$ & 0,011 & 0,049 \\
\hline poniewieski & 0,038 & 0,024 & 0,026 & 0,105 & $-0,219$ & $-0,086$ & 0,066 & 0,038 & 0,024 & 0,015 \\
\hline szawelski & 0,066 & 0,041 & 0,068 & 0,021 & $-0,156$ & $-0,071$ & 0,040 & 0,063 & 0,029 & 0,019 \\
\hline tauroski & $-0,031$ & 0,066 & 0,033 & $-0,015$ & $-0,086$ & $-0,090$ & 0,086 & 0,036 & 0,059 & $-0,088$ \\
\hline telszański & 0,110 & 0,007 & 0,053 & $-0,062$ & $-0,152$ & $-0,089$ & 0,042 & 0,088 & 0,057 & 0,072 \\
\hline uciański & 0,230 & $-0,020$ & 0,003 & 0,067 & $-0,062$ & $-0,181$ & $-0,040$ & 0,036 & 0,029 & 0,060 \\
\hline wileński & 0,078 & 0,056 & 0,027 & $-0,022$ & $-0,134$ & $-0,013$ & 0,051 & 0,036 & 0,056 & $-0,003$ \\
\hline
\end{tabular}

Źródło: opracowanie własne na podstawie danych Departamentu Statystyki Litwy.

W badanym okresie zmiany wartości syntetycznego miernika rynku pracy nie miały charakteru jednostajnego, wzrosty i spadki tego miernika występowały z różnym natężeniem w zależności od okręgu i roku. Dane z tabeli 3. pozwalają wyodrębnić trzy okresy rozwoju rynku pracy dla okręgów Litwy, a mianowicie:

- I okres: 2004-2007 lata - umiarkowany wzrost;

- II okres: 2008-2010 lata - duży spadek dla wszystkich okręgów;

- III okres: 2011-2014 lata - umiarkowany wzrost.

Szczegółową analizę zmian wartości syntetycznego miernika w czasie przedstawia rysunek 2. W 2005 roku w większości okregów rynek pracy Litwy osiagał najwyższy rozwój w badanym okresie. Największy przyrost wartości syntetycznego miernika rynku pracy w 2005 roku w porównaniu z 2004 rokiem odnotowano dla okręgu uciańskiego $(0,230)$, a najmniejszy - dla okręgu tauroskiego $(-0,031)$. W 2006 roku w porównaniu z 2005 rokiem dla wszystkich okręgów, oprócz uciańskiego, nastapił umiarkowany wzrost miernika rynku pracy (najwyższy w okregu olickim - 0,129). Na uwagę zasługuje fakt, że w 2006 roku w porównaniu z 2005 rokiem w okręgu uciańskim wartość syntetycznego wskaźnika rynku pracy spadła o 0,020. W 2007 roku w porównaniu z 2006 rokiem odnotowano tendencję wzrostowa. We wszystkich okręgach wartość syntetycznego wskaźnika rynku pracy w 2007 roku w porównaniu z 2006 rokiem wzrosła umiarkowanie. W 2008 roku skutki gospodarczego kryzysu wpłynęły na rozwój rynku pracy, gdzie w większości okręgów miał miejsce spadek wskaźnika rynku pracy. Największy przyrost wartości syntetycznego miernika rynku pracy w 2008 roku w porównaniu z 2007 rokiem zaobserwowano dla okręgu poniewieskiego $(0,105)$, a najmniejszy - dla okręgu telszańskiego $(-0,062)$. 
RYSUNEK 2.

Zmiany wartości syntetycznego miernika rynku pracy dla okręgów Litwy w latach 2004-2014

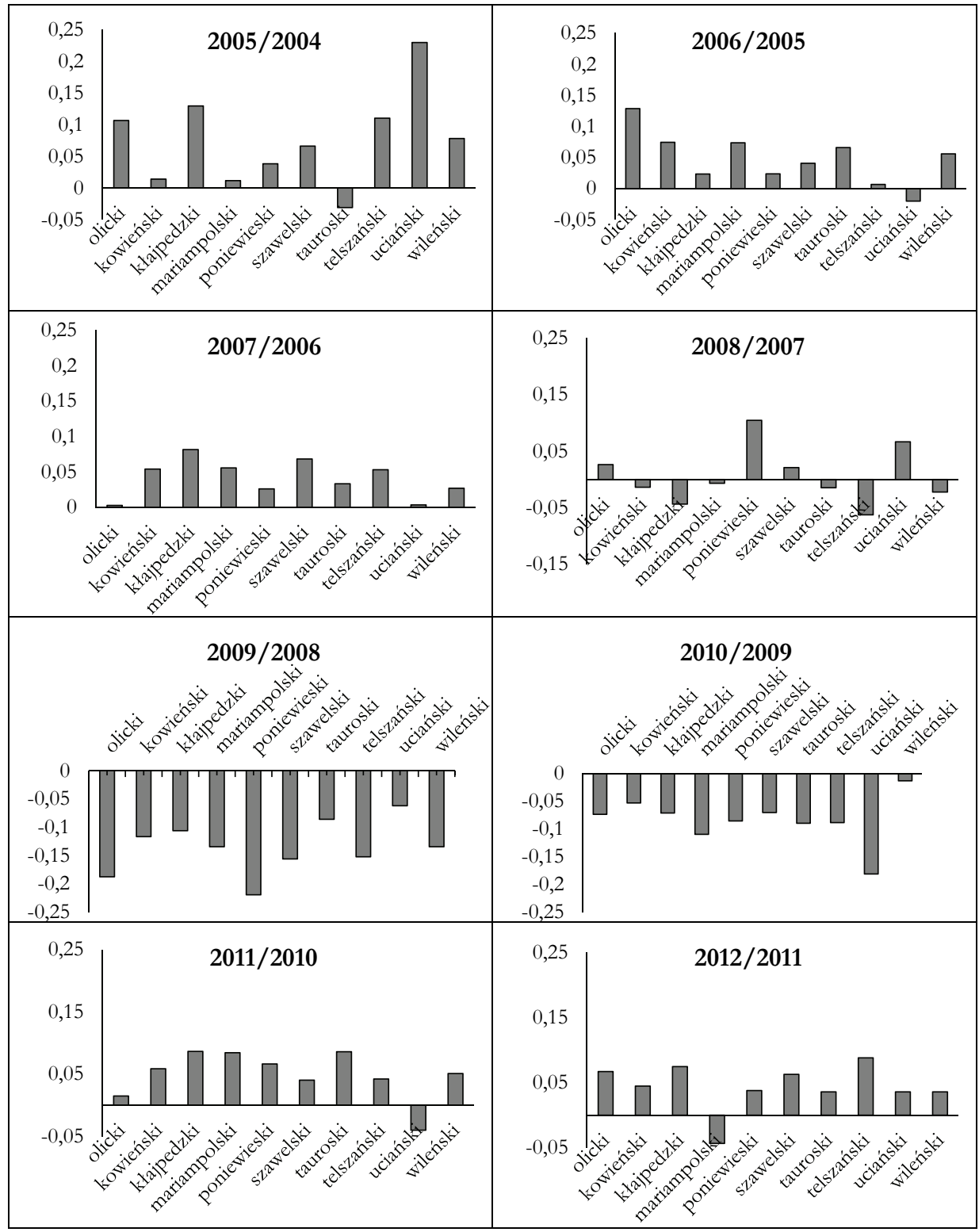




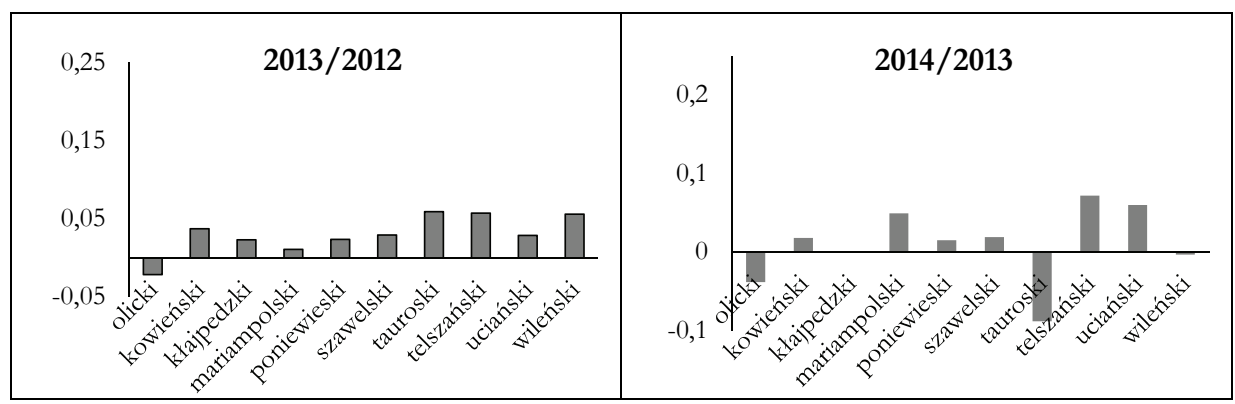

Źródło: opracowanie własne na podstawie danych Departamentu Statystyki Litwy.

W 2009 roku we wszystkich okręgach sytuacja na rynku pracy był najgorsza w badanych latach 2004-2014. We wszystkich okręgach w 2009 roku w porównaniu z 2008 rokiem wystąpił spadek wartości miernika rynku pracy. Podobna sytuacja utrzymała się w 2010 roku. W 2010 roku w porównaniu z 2009 rokiem we wszystkich okręgach stwierdzono niższy spadek wskaźnika niż sprzed roku. W 2011 roku w porównaniu z 2010 rokiem we wszystkich okręgach, oprócz uciańskiego, nastąpił umiarkowany wzrost miernika rynku pracy. W 2012 roku sytuacja niewiele zmieniła się na rynku pracy w okręgach Litwy. Największy przyrost wartości syntetycznego miernika z 2012 roku w porównaniu z 2011 rokiem odnotowano w okręgu telszańskim $(0,088)$, a największy spadek w okręgu mariampolskim (-0,043). W 2013 roku ogólnie miał miejsce nieznaczny wzrost miernika rynku pracy w okręgach Litwy. Dla trzech okręgów odnotowano podobny i największy przyrost tego miernika w 2013 roku w porównaniu z 2012 rokiem, tj.: w tauroskim $(0,059)$, telszańskim $(0,057)$ i wileńskim $(0,056)$. Jedynie dla okręgu olickiego wystapił spadek miernika rynku pracy (-0,021). W 2014 roku zaobserwowano spadek wskaźnika rynku pracy w okręgach Litwy. Wartość miernika rynku pracy w 2014 roku w porównaniu z 2013 rokiem umiarkowanie wzrosła dla sześciu okręgów. Niepokojącym zjawiskiem jest spadek miernika dla czterech okręgów, a mianowicie: olickiego (-0,038), kłajpedzkiego $(-0,001)$, tauroskiego $(-0,088)$ i wileńskiego $(-0,003)$.

RYSUNEK 3.

Współczynnik zmienności syntetycznego miernika rynku pracy dla okręgów Litwy w latach 2004-2014

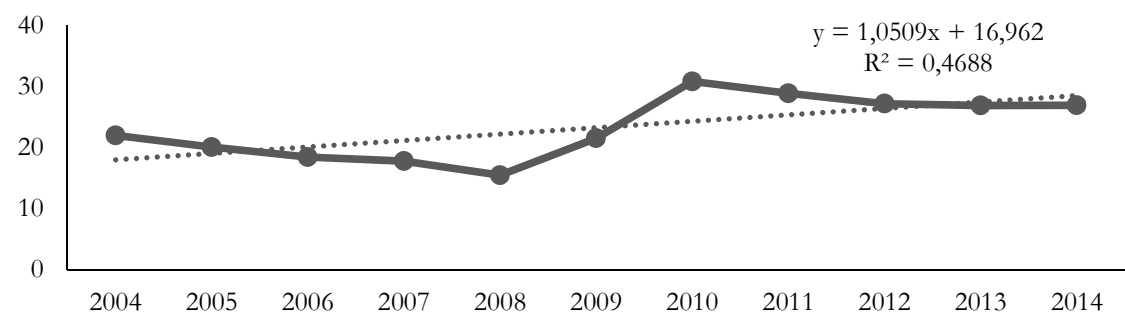

Źródło: opracowanie własne na podstawie danych Departamentu Statystyki Litwy. 
Dla współczynnika zmienności miernika rynku pracy wyznaczono krzywą trendu (rysunek 3.). Otrzymano zależność liniową ze współczynnikiem dodatnim (b=1,051), przy poziomie istotności 0,020, co świadczy o wzroście zróżnicowania okręgów Litwy w obszarze rynku pracy w latach 2004-2014.

Wykorzystując metodę Warda, dokonano grupowania regionów Litwy na skupiska okręgów, które są najbardziej podobne do siebie wewnątrz grup oraz najbardziej zróżnicowane z uwagi na poziom rynku pracy. Kryterium pogrupowania okręgów w skupienia polegało na ocenie podobieństwa lub odległości między analizowanymi obiektami pod względem wybranych siedmiu wskaźników. Warto zaznaczyć, że skupienia wyznaczone metodą Warda charakteryzowały się minimalną wariancją wewnątrzgrupową [Wójcik, 2009]. Otrzymane wyniki przedstawiono na rysunku 4.

Za pomoca metody Warda uzyskano skupiska okręgów podobnych do siebie pod względem rozwoju rynku pracy (tabela 4.). Delimitacja okręgów na grupy w latach 2004-2014 była dosyć zróżnicowana w kwestii składu i ilości grup. W badanym okresie niezmienny skład stanowiła jedna grupa, do której wchodziły kolejno okręgi: wileński, kowieński i kłajpedzki. Wyniki te potwierdzają to, że w badanym okresie dane trzy okręgi wyróżniały się bardzo dobrą sytuacją na rynku pracy oraz dużym międzyokręgowym zróżnicowaniem sytuacji na rynku pracy.

Okręg wileński był liderem z uwagi na: wskaźnik zatrudnienia, liczbę osób pracujących w sektorze usług na 1000 pracujących i liczbę absolwentów z wyższym wykształceniem na 1000 mieszkańców. Również w danym okręgu odnotowano najniższy udział osób z wykształceniem podstawowym/niepełnym w ludności w wieku 25-64 lata. W badanym okresie okręg tauroski posiadał najmniejszą liczbę osób pracujących w sektorze przemysłowym i liczbę absolwentów z wyższym wykształceniem. Jednocześnie charakteryzował się najwyższym udziałem osób z wykształceniem podstawowym/niepełnym. Do tego w latach 2004-2014, na zmianę z okręgiem telszańskim, w okręgu tauroskim zaobserwowano najmniejszą liczbę pracujących w sektorze usług. Zatem okręg tauroski należał do najsłabszych okręgów w badaniu rynku pracy.

Klasyfikacja okręgów na grupy metodą Warda pozwoliła wyodrębnić od dwóch do pięciu grup okręgów w ramach badanych wskaźników w danym okresie ze względu na poziom rozwoju rynku pracy. Przy czym, wysoki rozwój zaobserwowano w trzech okręgach, tj.: wileńskim, kowieńskim i kłajpedzkim. Warto zaznaczyć, że delimitacja okręgów Litwy w latach 2012-2014 wskazuje podział na dwie grupy. 
TABELA 4.

Klasyfikacja na grupy okręgów Litwy wyznaczonych za pomocą metody Warda, według poszczególnych lat, w okresie 2004-2014

\begin{tabular}{|c|c|c|c|c|c|}
\hline Rok & Grupa I & Grupa II & Grupa III & Grupa IV & Grupa V \\
\hline 2004 & $\begin{array}{l}\text { kowieński } \\
\text { wileński } \\
\text { kłajpedzki }\end{array}$ & $\begin{array}{l}\text { mariampolski } \\
\text { tauroski }\end{array}$ & $\begin{array}{l}\text { poniewieski } \\
\text { uciański } \\
\text { olicki } \\
\text { telszański } \\
\text { szawelski }\end{array}$ & - & - \\
\hline 2005 & $\begin{array}{l}\text { telszański } \\
\text { uciański } \\
\text { olicki } \\
\text { szawelski } \\
\text { poniewieski }\end{array}$ & $\begin{array}{l}\text { kowieński } \\
\text { kłajpedzki } \\
\text { wileński }\end{array}$ & $\begin{array}{l}\text { mariampolski } \\
\text { tauroski }\end{array}$ & - & - \\
\hline 2006 & $\begin{array}{l}\text { telszański } \\
\text { uciański }\end{array}$ & $\begin{array}{l}\text { poniewieski } \\
\text { szawelski }\end{array}$ & $\begin{array}{l}\text { kowieński } \\
\text { kłajpedzki } \\
\text { wileński }\end{array}$ & olicki & $\begin{array}{l}\text { mariampolski } \\
\text { tauroski }\end{array}$ \\
\hline 2008 & $\begin{array}{l}\text { kowieński } \\
\text { wileński } \\
\text { kłajpedzki }\end{array}$ & $\begin{array}{l}\text { olicki } \\
\text { mariampolski } \\
\text { poniewieski } \\
\text { uciański } \\
\text { szawelski } \\
\text { tauroski }\end{array}$ & telszański & - & - \\
\hline 2009 & $\begin{array}{l}\text { kowieński } \\
\text { kłajpedzki } \\
\text { wileński }\end{array}$ & $\begin{array}{l}\text { mariampolski } \\
\text { uciański } \\
\text { tauroski }\end{array}$ & $\begin{array}{l}\text { poniewieski } \\
\text { szawelski } \\
\text { olicki } \\
\text { telszański }\end{array}$ & - & - \\
\hline 2012 & $\begin{array}{l}\text { olicki } \\
\text { mariampolski } \\
\text { szawelski } \\
\text { tauroski } \\
\text { poniewieski } \\
\text { uciański } \\
\text { telszański }\end{array}$ & $\begin{array}{l}\text { kowieński } \\
\text { kłajpedzki } \\
\text { wileński }\end{array}$ & - & - & \\
\hline 2013 & $\begin{array}{l}\text { olicki } \\
\text { mariampolski } \\
\text { szawelski } \\
\text { poniewieski } \\
\text { telszański } \\
\text { uciański } \\
\text { tauroski }\end{array}$ & $\begin{array}{l}\text { kowieński } \\
\text { kłajpedzki } \\
\text { wileński }\end{array}$ & - & - & - \\
\hline 2014 & $\begin{array}{l}\text { mariampolski } \\
\text { szawelski } \\
\text { poniewieski } \\
\text { tauroski } \\
\text { telszański } \\
\text { uciański } \\
\text { olicki }\end{array}$ & $\begin{array}{l}\text { kowieński } \\
\text { kłajpedzki } \\
\text { wileński }\end{array}$ & - & - & - \\
\hline
\end{tabular}

Źródło: opracowanie własne na podstawie danych Departamentu Statystyki Litwy za pomocą SPSS 24. 
RYSUNEK 4. Grupowanie okręgów Litwy metodą skupień Warda ze względu na poziom rynku pracy w latach 2004-2014

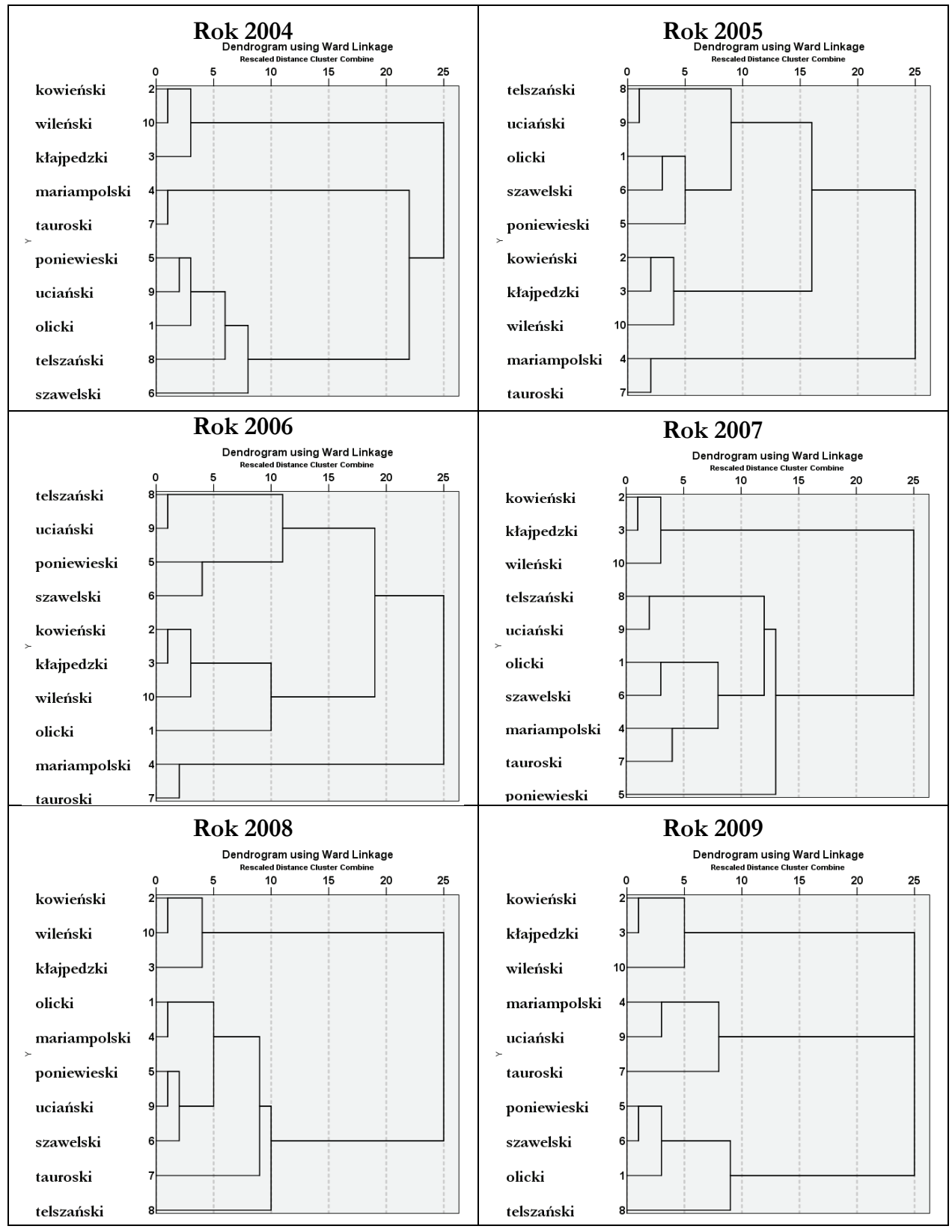




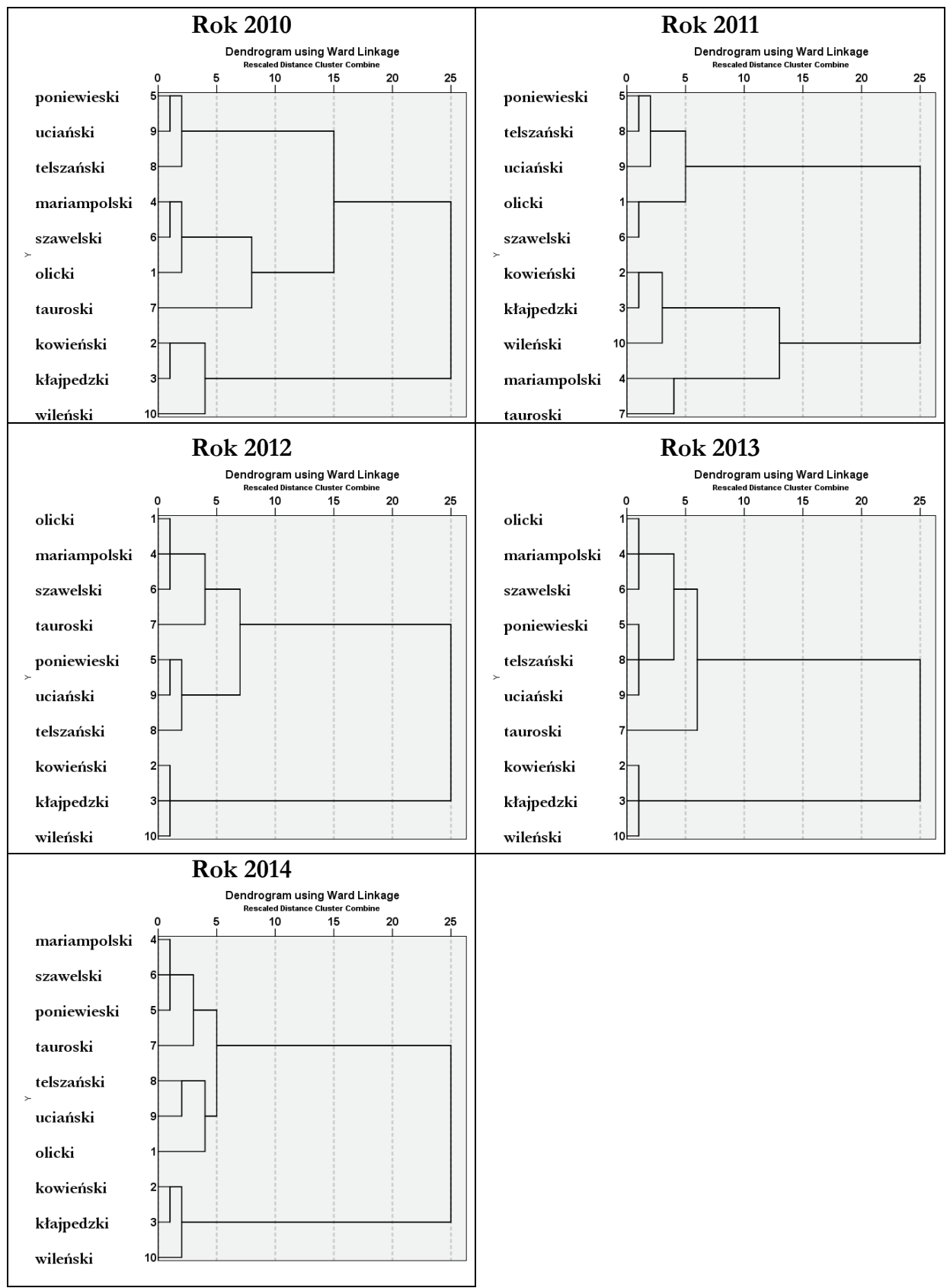

Źródło: opracowanie własne na podstawie danych Departamentu Statystyki Litwy. 


\section{Podsumowanie}

Analiza porównawcza sytuacji na rynku pracy dotyczyła okręgów Litwy w latach 2004-2014. Korzystajac z danych Departamentu Statystyki Litwy, wstępnie wybrano dwanaście wskaźników objaśniających sytuację rynku pracy z podziałem na podobszary tematyczne. Dany zestaw wskaźników na podstawie przesłanek merytorycznych i statystycznych zredukowano do siedmiu wskaźników, reprezentujących każdy podobszar tematyczny, które następnie wykorzystano do budowy syntetycznego miernika rynku pracy.

Wyniki przeprowadzonych badań pokazały poprawę sytuacji na rynku pracy dla wszystkich okręgów w 2014 roku w porównaniu z 2004 rokiem, przy jednoczesnym wzroście zróżnicowania międzyregionalnego rozwoju rynku pracy w badanym okresie. Podział okręgów ze względu na typologiczne klasy rozwoju, ocena zmian wartości miernika oraz metoda Warda potwierdziły stabilną i wiodąca pozycję okręgu wileńskiego, drugą lokatę okręgu kowieńskiego i trzecią kłajpedzkiego. Dla pozostałych okręgów zaobserwowano duże zróżnicowanie tempa oraz kierunków rozwoju rynku pracy w analizowanym okresie.

Warto zaznaczyć, że przeprowadzona analiza pozwoliła wyszczególnić trzy okresy rozwoju rynku pracy w okręgach Litwy, a mianowicie: I okres: 2004-2007 lata - umiarkowany wzrost; II okres: 2008-2010 lata - duży spadek dla wszystkich okręgów; III okres: 2011-2014 lata - umiarkowany wzrost. Trzeba także mieć na uwadze to, że zróżnicowanie poziomu rozwoju rynku pracy w poszczególnych okręgach zależy od takich czynników, jak: atrakcyjność położenia, dostępne zasoby siły roboczej, poziom kapitału ludzkiego, dostęp do infrastruktury społeczno-technicznej, jakość i poziom życia mieszkańców okręgu czy potencjał gospodarczy regionu.

Zastosowanie metod wielowymiarowej analizy porównawczej umożliwiło kompleksową ocenę zróżnicowania rozwoju rynku pracy Litwy w ujęciu regionalnym. Przeprowadzona analiza wybranych wskaźników rynku pracy dla okręgów Litwy jest pewnym sygnałem o pogarszającej się sytuacji na rynku pracy, a zatem i gospodarczej państwa. Należy również pamiętać, że zastosowane metody badawcze i wykorzystane wskaźniki objaśniające rynek pracy sa jedna z propozycji związaną z pomiarem zróżnicowania poziomy rynku pracy dla okręgów Litwy.

\section{Wkład autorów w powstanie artykułu}

dr hab. Ewa Roszkowska, prof. UwB - koncepcja badania, współudział w przeprowadzeniu badania i opracowaniu wyników $-60 \%$, mgr Regina Lašakevič - zebranie danych, współudział w przeprowadzeniu badania i opracowaniu wyników $-40 \%$. 


\section{Literatura}

Beržinskienè, D., Rudytè, D., 2008, Jaunimo padeties Baltijos šaliu darbo rinkose dinaminiu pokycrú lyginamoji analizé, ,Ekonomika ir vadyba: aktualijos ir perspektyvos”, $\mathrm{nr} 3$ (12). Bosworth D., Dawkins P., Stromback T., 1996, The Economics of the Labour Market. Longmann, Harlow, Essex.

Braziene R., Dorelaitienè A., 2013, Transition of Youth from Education to the labour market: the case of Lithuania, "Social Sciences", vol. 77, iss. 3.

Čiburienè J., Guščinskienè J., 2008, Darbo rinkos pokyycriai integracijos $\dot{z}$ Europos sajunga salygomis, „Economics \& Management”, nr 13.

Hellwig Z., 1990, Taksonometria ekonomiczna, jej osiagniecia, zadania i cele, „Taksonomia teoria i zastosowania", Wydawnictwo Akademii Ekonomicznej w Krakowie, Kraków.

Kryńska E., Kwiatkowski E., 2010, Polityka państwa wobec rynku pracy: idee ekonomične i ræecsymistość, „Polityka Społeczna”, nr 5-6.

Kwiatkowski E., Kubiak P., 1996, Regionalne zróżnicowanie bezrobocia w Polsce w latach 1992-1995. Analiza strumieniowa, „Rynek Pracy”, nr 9.

Laužadytè A., Samoškaite G., 2013, Darbo rinka Lietuvoje: situacija ir politika, „Public Administration", vol. 1, iss. 37.

Łuczyńska J., 2015, Kapitat ludžki jako caynnik rozwoju regionalnego na Litwie, Wydawnictwo Uniwersytetu w Białymstoku, Białystok.

Majka A., 2015, Taksonomiczna analiza zróżnicowania poziomu ṡycia w Polsce, Prace Naukowe Uniwersytetu Ekonomicznego we Wrocławiu, nr 407.

Malina A., 2014, Wielonymiarowa analiza præ̌estržennego zróżnicowania struktury gospodarki Polski wedtug województw, Zeszyty Naukowe, nr 162, Wydawnictwo Akademii Ekonomicznej w Krakowie, Kraków.

Młodak A., 2006, Analiza taksonomiczna w statystyce regionalnej, Wydawnictwo Difin, Warszawa.

Perło D., 2014, Modelowanie zrónnoważonego roz̨uoju regionón, Wydawnictwo Uniwersyteckie Trans Humana, Białystok.

Perło D., Roszkowska E., 2011, Zastosowanie wybranych metod klasyfikacji do analizy zróm-

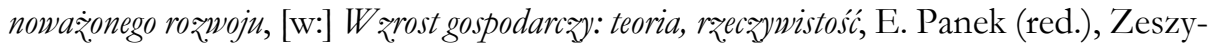
ty Naukowe Uniwersytetu Ekonomicznego w Poznaniu, nr 176, Poznań.

Polityka rynku pracy: teoria i praktyka, 2015, M. Frączek (red.), Polskie Wydawnictwo Ekonomiczne, Warszawa.

Portal Departamentu Statystyki Lituyy, http:/ /osp.stat.gov.lt/ (data wejścia: 10.03.2017).

Roszkowska E., Filipowicz-Chomko M., 2016, Ocena rozwoju społecznego wojewódzৃtw Polski w latach 2005-2013 w kontekśsie realizacii koncepgi zrównoważonego rozuoju z wykorayystaniem metody TOPSIS, „Ekonomia i Środowisko”, nr 2(57).

Roszkowska E., Karwowska R., 2014, Wielowymiarowa analiza poziomu zৃónnoważonego rozpoju województw Polski w 2010, „Economics and Management”, nr 1.

Stownik DSL, http://osp.stat.gov.lt/statistikos-terminu-zodynas (data wejścia: 10.03.2017). Socha-Sachalin S., 1998, Transformacja rynku pracy, Wydawnictwo Politechniki Koszalińskiej, Koszalin. 
Sokołowski A., 1984, Wybrane zagadnienia pomiaru $i$ ważenia cech w taksonomii, Zeszyty Naukowe Akademii Ekonomicznej w Krakowie, nr 203.

Ustawa z dnia 31 października 2007 roku - Dèl ekonominès veiklos rüsiu klasifikatoriaus patvirtinimo, Dz. U., 2007, Nr 119-4877, http://osp.stat.gov.lt/static/evrk2.htm (data wejścia: 02.01.2017).

Vaitekūnas S., 2008, Lietuvoš̌mogiškieji ištekliai: dabar ir galimi ateities variantai, „Tiltai“, V. 44, I. 3.

Vaitekūnas S., Stefanenkova E., 2011, Lietuvoš̌mogiškuju ištekliu geoekonominè struktūra, „Tiltai”, V. 54 I.1.

Verkulevičiūtè-Kriukienè D., 2015, Labour income and the unemployment rate in the regions of Lithuania, Latvia and Estonia: differences and change in the period 2004-2013, "Regional Formation \& Development Studies", I. 16.

Vetlov I., Virbickas E., 2006, Lietuvos darbo rinkos lankstumas, "Monetary Studies (Bank of Lithuania)", V. 10, I. 1.

Wrrost gospodarczy, rynek pracy, innowacyjnośc gospodarki, 2012, W. Kasperkiewicz, K. Madaj (red.), Wydawnictwo Uniwersytetu Łódzkiego, Łódź. 